\title{
Introduction
}

Cross-sectional and longitudinal studies have shown that, on average, body composition changes with aging, with an increase in fat mass and a decrease in muscle mass $(1,2)$.

In both, men and women, normal weight and obese subjects, body weight tends to increase, peaking at about age 65 years in men and later in women, and then decreasing with further aging (3).

However even without body weight changes, the amount of fat significantly increases with age (4).

Body fat distribution also changes with age, with an increase in visceral fat and a decline in subcutaneous fat (5).

\footnotetext{
${ }^{1}$ Corresponding author: M Zamboni, M.D. Cattedra di Geriatria, Università di Verona, Ospedale Maggiore, Piazzale Stefani 1, 37126 VERONA, Italy, +39-45-8122537, +39-45-8122043 (fax), mauro.zamboni@univr.it.
} 
With aging there is also loss of muscle mass, a process called sarcopenia (6) and an increase of the amount of fat inside and around muscles (7).

Age-related body composition changes have been shown to be related to both metabolic and functional disorders (8).

Previous studies showed that fat-free mass is associated with disability $(6,9-12)$. This result has been confirmed in longitudinal observational studies showing that loss of appendicular and legs fat-free mass measured by DXA predicted worsening disability (13).

Body fatness is associated with cardiovascular disease and physical disability (14).

In a group of elderly women, higher BMI and body fat as evaluated by DXA predicted functional impairment and disability more than markers of sarcopenia $(8,15-17)$. Previous studies found that obesity increases the risk of subsequent functional limitations and disability in middle-aged and older adults $(18,19)$. In a more recent study it has been suggested that both abdominal fat and total body fat in middle adulthood may contribute to subsequent functional limitations and disability among African-American and white men and women, confirming that abdominal fat may have an independent effect on functional limitations and disability (20).

Few studies examined the associations between abdominal fat and subsequent functional limitations and disability, even though there is a tendency towards increased abdominal fat distribution with increasing age $(21,22)$.

Fat infiltration into the muscle correlates with low extremity performance and predicts future mobility limitation $(23,24)$.

It may be possible that the loss in muscle and the gain in fat act synergistically to cause disability or metabolic disorders. Recently the concept of sarcopenic obesity has been proposed (25) and its relation with physical impairment and disability has been investigated. The concept of sarcopenic obesity should help to understand the complexity of the relation between obesity and mortality and morbidity in the elderly. Sarcopenic obesity may be not recognized with the use of BMI, and thus its effect on mortality and morbidity is likely underestimated.

Thus the evaluation of body composition should be relevant in old subjects when assessing their risk of functional decline.

\section{Body composition methods and models}

Body composition analysis allows the division of the human body in different compartments based on the different physical properties. Fat-free mass is a heterogeneous compartment that can be further divided into its primary constituents of water, protein and mineral.

The two level body composition model subdividing the whole body in FM and FFM based on these constituents is the most used in epidemiological and clinical studies. 
The density of any material is a function of the proportion and densities of its components. In the classic two-compartment model of body composition, human body is divided in fat mass (FM) and fat free mass (FFM). therefore,

$$
\mathrm{I} / \mathrm{D}_{\text {body }}=\mathrm{F} / \mathrm{D}_{\mathrm{FM}}+\mathrm{FFM} / \mathrm{D}_{\mathrm{FFM}}
$$

where I/D equals body mass, set equal to unity, divided by body density and F/D $/ \mathrm{FM}_{\mathrm{F}}$ and FFM/D $D_{\text {FFM }}$ are the proportions of the fat and fat-free masses divided by their respective densities. On the basis of limited data from chemical analyses of animal carcasses and human cadavers $(26,27), \mathrm{D}_{\mathrm{FM}}$, water, proteins and minerals have been measured, and an estimate of $\mathrm{D}_{\mathrm{FFM}}$ has been derived.

The two level body composition model is classically based on three assumptions. First, total body water is in constant relationship with FFM corresponding to $73.2 \%$, the so called "hydration law", following this equation:

FFM $=$ total body water / 0.732. fat mass is then calculated as the difference between body mass and FFM.

Second, the measure of total body potassium provides the best index for body cell mass (28) and therefore in the FFM. In fact chemical analyses have shown that potassium is essentially an intracellular cation that is not present in stored triglycerides. For this reason it is considered to be a valid indicator of FFM, because more closely linked to the cell mass than to the extracellular compartment (29). Third, nitrogen and protein exist in a stable relationship within and between subjects with a constant ratio of 1.6 for all muscle mass component, collagen, albumin and actino-myosin. Under normal conditions more than $99 \%$ of total body nitrogen is incorporated in proteins and proteins are the most significant part of the FFM (30).

However accuracy of these three assumptions when applied to the elderly population has not been proven.

Nonetheless, using these values and solving for FM, we can derive formulas for calculating percent body density based on two-component, three-component and four-component models, the Siri equation \% Fat $=\left(4.95 / \mathrm{D}_{\text {body }}-4.50\right) \times 100$ and the Brozek equation (26) \% Fat $=\left(4.570 / \mathrm{D}_{\text {body }}-4.142\right) \times 100$ are the simplest and most common fat-estimating formulas. the validity and accuracy of any equation depend on whether the assumed fractions and densities of the body components represented in the underlying model are appropriate for the person being measured. A variety of studies have demonstrated considerable variation in FFM composition and density attributable to growth and maturation, aging and specialized training. Moreover sex and racial differences determine considerable inter-individual variation that challenge the assumption of FFM chemical constancy. Consequently, three-component and four-component equation are more valid and accurate, because they require fewer assumptions, although the potential for introducing greater measurement error exists.

In the last decades the development of new technological tools applied to the study of body composition has gone hand in hand with its application to the study of disability and age- 
associated changes in body composition. These methods are discussed below and caveats regarding their use in old age are identified where appropriate.

Considering the use of body composition analysis in the elderly, some limitations must be acknowledged and the assumptions underlying these techniques must be carefully considered. Body composition might be carried out to assess relative change with diet or with exercise or might be used as an endpoint in a clinical trial. At this time there are no age-specific clinical diagnoses for which imaging of muscle is necessary. Some instruments, such as CT and MRI, the "gold standards", produce more accurate data and are considered the reference methods for muscle mass quantification, muscle quality and fat distribution evaluation. On the other hand, these methods have disadvantages of cost, limited availability and are used only for research. More of the strengths and limitations are discussed below.

\section{Methods for Muscle mass evaluation}

In the last years an increased awareness of the significance of maintaining skeletal muscle mass (SMM) has stimulated a growing interest in different approaches for the in vivo assessment of SMM. In the adult, the majority of muscle is found in the legs, with lesser amounts in the head, trunk and arms. In older subjects it has been shown that lower extremity muscle mass is associated with disability. Several methods have been proposed to evaluate muscle mass.

\section{Anthropometry}

Anthropometry has been used to evaluate FFM. This method requires the selection of body measurements predictive of muscle mass: muscle groups are generally selected with the assumption that site-specific measurements reflect the mass of that specific muscle. The mass of the estimates muscle group is directly proportional to the whole-body skeletal muscle mass (31).

Anthropometric measurements has been used to predict regional and total muscle mass. Among the regional measurements of muscle mass, historically the evaluation of the upper limb (i.e. midarm circumference) was the most frequently used.

For this measurement the subject stands erect, with the arms hanging freely at the sides of the trunk and with palms facing the thighs. The subject wears loose clothing without sleeves to allow total exposure of the shoulder area. The midpoint of the upper arm has been marked for the measurement of triceps or biceps skinfolds, this should be used as the level for the measurement of arm circumference. The measurer stands behind the subject and locates the lateral tip of the acromion by palpating laterally along the superior surface of the spinous process of the scapula.

A small mark is made at the identical point. The most distal point on the acromial process is located and marked. a tape is placed so that is passes over these two marks, and the midpoint between them is marked. the tape is positioned perpendicular to the long axis of the arm at the marked midpoint, and the circumference is recorded to the nearest $0.1 \mathrm{~cm}$. 
Assumption for its use was that the midarm is circular, the triceps skinfold thickness is twice the average fat diameter at the middle of the upper arm and the bone responds in a similar manner to muscle and fat during growth (31). Heymsfield and collegues reported that all these three assumption need to be better clarified in the elderly. In a sample of normalweight to overweight adults anthropometric midarm muscle area as evaluate with anthropometry was overestimated $15 \%$ to $25 \%$ compared with reference values determined by computed axial tomography (32). Sex specific equations were derived containing corrections for bone contributions, resulting in average intraindividual error of $7 \%$ to $8 \%$ in the calculated midarm muscle area. By using this formula in obese subjects an average $50 \%$ error was observed.

More recently Lee et al (33) developed and evaluated the predictive accuracy of a new anthropometric model using magnetic resonance imaging (MRI) as reference method in a population of 244 non obese adults: their predictive equation used upper-arm girth adjusted for skinfold, thigh circumference corrected by anterior thigh skinfold and height, and calf circumference corrected by skinfold thickness.

$\mathrm{SMM}=\mathrm{S}\left(0.00744 \mathrm{CAG}^{2}+0.00088 \mathrm{CTG}^{2}+0.00441 \mathrm{CCG}^{2}\right)+2.4 \mathrm{Sex}-0.048 \mathrm{Age}$

where CAG is corrected upper-arm girth adjusted for skinfold thickness, CTG is thigh circumference corrected for anterior thigh skinfold thickness, CCG is calf circumference corrected for skinfold thickness, $\mathrm{S}$ is stature in $\mathrm{m}$, age is in years, sex is 1 for male and 0 for female, and race is -2 for Asians, 1.1 for African American, 0 for white or Hispanic. These authors found no significant difference between MRI-measured and predicted SMM in the validation group.

In general the use of anthropometric measurements, including circumference and skinfold thickness to predict total and regional muscle mass yields quantitative assessment. Moreover it is not known if anthropometric estimation are either sufficiently sensitive to monitor small changes in muscle mass observed with age-associated body composition changes. Information is not available about accuracy of skinfold thickness assessment in elderly subjects in particular when they are ill.

\section{Bioelectrical impedance analysis (BIA)}

BIA is widely used for assessing muscle mass. This method relies on the conduction of an applied electrical current to a conductor volume and measures two parameters: resistance $(\mathrm{R})$ and reactance $(\mathrm{Xc})$. Reference body composition data to validate the BIA-based measures was derived from anthropometric assessment and CT measurements of muscle and fat area.

Several equations have been suggested to estimate muscle mass by BIA (34).

In 1997 Roubenoff and colleagues (35) developed BIA equations to evaluate FFM in the elderly men and women by using data from 455 participants in the Framingham Heart Study (78 y; $27.3 \mathrm{~kg} / \mathrm{m} 2)$, using dual-energy x-ray absorptiometry (DXA) as a reference technique:

Men: $9.1536+0.4273$ height $^{2} / \mathrm{R}+0.1926$ weight $+0.0667 \mathrm{Xc}$ 
Women: $7.7435+0.4542$ height $^{2} / \mathrm{R}+0.1190$ weight $+0.0455 \mathrm{Xc}$

where height is in cm, age in years and $\mathrm{R}$ in ohm; sex: male $=1$, female $=0$.

It was later shown that the Roubenoff equation overestimated FFM in taller/less obese New Mexico Study subjects (36).

A regression equation was validated to estimate skeletal muscle mass (SMM) in a multiethnic sample of 388 men and women aged 18 to 86 years (37):

$$
\mathrm{SMM}=0.401(\mathrm{Ht} 2 / \mathrm{R})+3.825 \mathrm{Sex}-0.071 \text { Age }+5.102
$$

where $\mathrm{R}$ is resistance $(\mathrm{ohm})$ determined at $50 \mathrm{kHz}, \mathrm{Ht}$ is height $(\mathrm{cm})$, sex is male $=1$ and female $=0$, and age is in years.

In a study proposing a comparison between skeletal muscle mass as evaluated with total body MRI and with BIA no significant differences were observed between predicted and MRI-measured skeletal muscle mass values. However further analyses with the BlandAltman plot indicated there was a systematic error of bioimpedence in predicting skeletal muscle mass $(r=0.20, p<0.01)$. This error was small, 2 to $3 \%$ of the MRI-measured value (37).

The use of general prediction equations across ethnic populations without prior testing of their validity should be avoided, because of existing differences in body build among ethnic groups. The inhomogeneous nature of the various body compartments, large variations in cross-sectional areas and differences in conductor lengths from limbs and trunk are likely responsible for the lack of portability of BIA equations from one population to another, such as from young to elderly subjects, or from normal weight to obese or severely underweight subjects (38). Failing to adjust for differences in FFM hydration fraction in ethnic groups may result in systematic biases (39).

Bioelectrical impedance is a easy to use, widely available instrument for routine use. Actually some caution is needed when using BIA to assess body composition because of some confounders such as the presence of oedema, the need of stable clinical conditions or the need for stable "water conditions".

Caution is particularly important for elderly subjects because they need special equations. The NIH technology assessment report provided recommendations for the direction of research and clinical investigation of BIA (39): this report states that in general arm and leg impedance, an alternative that has been suggested for measurement of peripheral muscle mass, is less predictive of FFM than whole body impedance and presents a limitation of commercial impedance analyzers.

However, BIA is a convenient method to assess body composition in epidemiological studies only as far as population-specific prediction formulas are used (40); there is no agreed on general equation for body composition from BIA and what appears to best predict body composition within any study is a study-specific equation derived internally in the study. In the literature there are several prediction equations for BIA, generally developed from younger populations, and their accuracy in the elderly has not been adequately 
confirmed. Age-specific prediction equations of BIA have been suggested for assessing body composition in the elderly (41-44). Moreover, their generalized application to other elderly populations is limited by the fact that BIA equations are population specific and need to be validated in the actual population in which they are to be applied (35).

Forbes and coworkers (45) questioned the ability of impedance to determine the validity of repeated estimates of body composition from the same individuals, therefore in longitudinal observational or intervention studies. Resistance is proportional to the number of ions in a conductor, and a change in the composition that affects the number of ions should be reflected in the value of resistance. If a change in weight is predominantly fat, it will not be easily detected by resistance unless a sufficient change in FFM or TBW has occurred.

However, other studies that investigate the ability of BIA to measure body composition changes in the elderly are needed.

\section{Dual Energy X-ray Absorptiometry (DXA)}

DXA is a radiographique technique that offers a unique opportunity for direct measurement of muscle, fat and bone mass.

This technique, originally developed for bone mineral content assessment, has been refined for assessment of soft tissue composition. DXA exposes the patient to $\mathrm{X}$ ray although the amount of radiation exposure is much less compared with computer tomography (CT) (46). Dual X ray scanning systems include a X ray source collimated into a beam that passes in a posterior-to-anterior direction through bone and soft tissue and enters a detector situated over the scan area (Figure 1). Software algorithms are used for the analysis of X-ray attenuation. First, the attenuation related to bone is determined, followed by the attenuation attributable to soft tissue. The distinction between fat and fat-free mass is calculated considering the ratio between beam attenuation at the lower energy relative to that at the higher energy. In this way it is possible to estimate regional and whole body body mass content (BMC) and bone area, together with the quantification of lean soft tissue with appropriate computer software (Figure 2).

A summary of recent validation studies by Lohman et al (44) indicate good agreement between DXA and multicompartment models, with multicompartment models considered as reference methods.

Wang et al validated DXA skeletal muscle mass assessment against CT and neutron activation analysis (48). The CT procedure required a total of 22 cross-sectional slices taken at specific locations in the body. The predictive capacity for muscle mass for DXA versus CT showed a SEE of $1.6 \mathrm{~kg}(\mathrm{r} 2=0.91)$ lower than that observed for neutron activation analysis (SEE of $4.4 \mathrm{~kg}$ ).

Second generation DXA are equipped with fan-beam technology that allows much less time to complete whole-body composition and bone density scan with improved precision (49). Fan beam machine have been used frequently in clinical trials and also in the National Health and Nutrition Survey IV. Only a limited number of validation studies have been conducted with fan-beam DXA and a multicompartment method. When the Hologic 4500A 
was compared with both the 4 compartment model and body water there was a systematic overestimation of FFM (50-54). Body composition studies with DXA fan-beam and pencilbeam have found that the fan beam measurement overestimate lean mass with on the counterpart an understimation of fat mass with differences between various hardware and software mainly between $1 \%$ and $5 \%$ for different tissues. For Hologic 4500A, compared with both the $\mathrm{C}$ model and body water technique, previous research has shown that even with modification of the software to minimize effects of magnification (55) there is a systematic overestimation of FFM $(50,52,56)$. Tothill (57-58) compared fan- and pencilbeam DXA finding differences between $0.5 \%$ and $19 \%$ in regional and total body composition, emphasizing the importance of separate calibration with the same step phantom for studies using different instruments.

DXA allows also regional body composition assessment and in particular appendicular lean mass. Heymsfield et al (59) compared the estimates of appendicular lean mass as assessed with dual-photon absorptiometry with the measurements of TBK, TBN and anthropometric measurements of regional muscle mass. Variability of repeated measures in a subsample of four volunteers was 7\%, 2.4\% and 3\% respectively for arm, leg and combined appendicular muscle mass.

Potential interference of fluid accumulation in the body should be considered even when using DXA. In fact Horber et al (60) considered the effect of hemodialysis and food consumption on DXA estimates of body composition. The consumption of 1 to $2.4 \mathrm{~L}$ of water 1 hour before DXA scan result in a prevalent increase of FFM, because of alteration of extracellular fluid volume, whilst the ingestion of small amount of water didn't affect estimates of body composition. Horber also showed (in six subjects) that after dialytic treatment, body weight decreases 1 to $4.4 \mathrm{Kgs}$ with a prevalent decrease in FFM which accounted for more or less $95 \%$ of the change in body weight. The greater decline in muscle mass was observed in the trunk, suggesting that areas of the body with higher excess water and salts in patient with end stage renal disease are the regions in which the main decrements in FFM are observed after dialysis.

It is generally accepted that DXA is a reasonable alternative for muscle mass assessment compared to much more sophisticate, time consuming and expensive techniques such as MRI and CT. DXA likely represents the most accessible technique for high quality body composition assessment. The radiation exposure associated with DXA is low and highly acceptable (i.e., about $1 \mathrm{mrem}$; similar to that of a 3-day background). Nevertheless, even this low dose radiation needs to be considered as a limiting factor for routine assessment of body composition.

The main limitations of this imaging approach reside in the instrument cost, in some analytical differences existing across manufacturers and models, and the risk of biased results due to the poor differentiation between water and bone-free lean tissue. Another limitation is given by the dimensions of the table of the densitometer which is limited in size and therefore may not be suitable for the evaluation of subjects with obesity (Table 1). In fact, studies in elderly obese have then required the use of approximations such as the 
evaluation of mid-body (61) or one arm, starting from the assumption that lean body mass, fat and bone of the controlateral arm were similar.

\section{Imaging Methods \\ Computer Tomography (CT)}

CT scan is based on X-rays that pass through the different body tissues and are attenuated in relation to the physical density of the tissues examined. Software is able to quantify this physical effect and convert it into linear attenuation coefficients relative to water, all expressed in Hounsfield units, $-1000,-70$ and 20 respectively for air, adipose tissue and muscle (Figure 3).

Typically the range from -190 to $-30 \mathrm{HU}$ denote adipose tissue, whereas pixels that range from 0 to 100 denote skeletal muscle (62)

Each CT image is reconstructed by the software from pixels usually $1 \mathrm{~mm} \times 1 \mathrm{~mm}$ in dimension. A third dimension is slice thickness. Because the volume of each pixel can be calculated, the volume of skeletal muscle and adipose tissue in each slice can be determined from the number of pixels forming each slice and then added for all slices performed. The CT method offers high quality images with clear distinction between fat and other soft tissues.

This allows a clinician to visually and mathematically distinguish the different tissues with dedicated software (Figure 4) and in particular at the muscle level to separate intermuscular adipose tissue for mean skeletal muscle based on the differences in attenuation characteristics (63). Although CT offers considerable promise as a method to assess muscle mass, there are limited data on comparison with other methods. Wang et al (64) compared skeletal muscle mass evaluated with CT and DXA versus indirect measures such as anthropometry, endogenous creatinine and 3-methyl-histidine excretion, finding no difference between estimates derived by CT and anthropometry, whereas the other techniques resulted in discrepancies compared to CT. Hudash et al (65) reported that the coefficient of variation (CV) for repeated measures of skeletal muscle area in the thigh was $0.7 \%$ and $1.4 \%$ for intra and inter-rater reliability respectively.

The high precision of CT, with $<1 \%$ of error, makes it the best method to measure physiological change in body composition of humans and the effect of life style interventions in this population.

Borkan et al (66) showed that muscle area as evaluated by CT, decreases with ageing.

More recent findings from the Health ABC study group clearly confirmed the age-related decline in muscle mass as evaluated by CT even in weight stable individuals (67).

Several years ago in a strength training study of nonagenarians Fiatarone et al (68) by using CT scans at thigh level showed a significant increase in quadriceps in response to strength training. 
The most important limitation for the routine use of CT exposes individuals to ionizing radiation (i.e., about 15 mrem, much higher than DXA) and provide a marker of fat content but not a quantitative determination of fat content (69). Advantages are the availability and the relative simplicity. It must be noted that $\mathrm{CT}$ imaging analysis, compared to MRI and magnetic resonance spectroscopy (MRS), allow a objective and high reproducible method for intermuscular fat evaluation based on pixel-by-pixel Hounsfield attenuation coefficients.

\section{Magnetic resonance imaging}

The basis for MRI is the fact that atomic nuclei behave like magnets. in fact when a magnetic field is applied across the body causes each nucleus to align with the field. Exposing the body to a radio-frequency electromagnetic wave some nuclei absorb the energy from the magnetic field. In a second moment the electromagnetic wave is turned off and as consequence the activated nuclei emit the radio signal that they previously absorbed, realigning themselves, a process called relaxation. This signal is used to create the image of the chemical composition of the tissue with a computer.

MRI has been used to assess FFM in human subjects (70). To calculate total body fat free mass and fat mass transverse slices of $10 \mathrm{~mm}$ thickness were acquired with $50 \mathrm{~mm}$ intervals from the head to feet and the volume of the respective tissues was calculated by multiplying the tissue area by the slice thickness and adding volumes of truncated pyramids defined by pair of adjacent slices. Comparison with anthropometric predictions of FFM showed a variability between $3.6 \%$ and $6.5 \%$ for men and women respectively (71). Mitsiopoulos (72) and Janssen (37) reported CVs for repeated measures in vivo MRI measures of skeletal muscle in six subjects of $2.9 \%$ and $2 \%$ for intra and inter-rater reliability respectively.

Several studies support the validity of MRI estimates to quantify skeletal muscle by comparison with the dissection in human cadavers. Mitsioupoulos et al (72) compared the cross-sectional area measurements of skeletal muscle and subcutaneous adipose tissue determined from the entire arm and leg regions of cadavers with corresponding MRImeasured cross-sectional areas and reported that the correlation coefficient between the two approached unity.

Limitations for the use of MRI in body composition studies are attributed to limited access of instrumentation, the higher technical complexity and costs, time required for scan acquisition (about $45 \mathrm{~min}$ ), and the inability to evaluate subjects with older models of implanted metal devices (e.g., joints, pace-makers, metallic particles in the eye, etc.). On the other hand, the magnetic resonance imaging (MRI) presents a high agreement with the CT and provides similar measures. It does not involve radiation exposure, and also has the additional capacity of multiple slice acquisition (thus, rendering 3D volumetric estimates for muscle mass). In particular, the lack of radiation exposure makes MRI the method of choice for many studies where ethics committee or national authority approval is more difficult tough to obtain for CT, but it must be considered that CVs for MRI are about two to three time greater than those reported for studies using CT. 


\section{Methods for fat mass evaluation}

There are many techniques, including underwater weighing, anthropometry, body water dilution, impedance, and dual-energy X-ray absorptiometry, that have long been used to estimate total, and, in the case of dual-energy X-ray absorptiometry, peripheral body fat content with varying degrees of accuracy. However, until the advent of X-ray computed tomography and magnetic resonance imaging (MRI), it had not been possible to differentiate between subcutaneous and internal fat reserves. This is important as it is thought that internal fat, in particular visceral fat, may be a key factor in disease development.

High technology methods such as CT and MRI are considered the gold standard for fat mass evaluation and are also used to assess adipose tissue, a component at the tissue level of body composition (73), with high accuracy and high cost. Other instruments such as DXA and air displacement plethysmography, estimate total body fatness, a component at the molecular level consisting mostly of triglycerides, with considerable accuracy. Considering the fact that adipose tissue is mostly composed by fat (80\%), and that fat is present also inside other tissues, total body fat and adipose tissue mass are not identical.

In NHANES III, body fat increased progressively with age until 70 years when it declined, along with body weight (74).

\section{Anthropometry and skinfold thicknesses}

The use of skinfold thickness to predict \%BF or body density is based on the assumption that measurements of skinfold thicknesses at a few sites provide an adequate description of subcutaneous adipose tissue and there is a fixed relationship between SCAT and deep adipose tissue.

Lohman et al showed that despite the relatively high correlation between skinfold and \%BF, no single measurement site on the body provides an accurate predictor of $\% \mathrm{BF}(75)$. In fact it must be considered that every individual has a different distribution of SCAT and a different proportion of SCAT on total body fat. There are sex and age related differences in the relationship between skinfold thickness and and \% BF (76). Generally women, for similar BF\%, have thinner skinfolds compared to men and older subjects have thinner skinfolds compared to young adults. Equations based on the measurements of more than one skinfold thicknesses have been proposed to increase the prediction of $\% \mathrm{BF}$ in the elderly. However it must be keep in mind that the use of these equations may still induce underestimation of fat mass in the elderly.

\section{DXA}

A summary of recent validation studies by Lohman and co (77) indicate that DXA and multicompartment models are in agreement in terms of mean values for body fat. In general, good agreement has been shown between pencil and fan beam DXA $(78,79)$ although an underestimation of FM using fan-beam DXA Hologic 4500 was found by Salamone (80).

Salamone and collegues (80) showed that DXA measurements are in agreement with CTmeasured body fat in the elderly with a prediction of FM with a SE of the estimate ranging 
from 1.4 to $1.6 \mathrm{~kg}$. DXA fan-beam showed a tendency to overestimate total leg and total thigh fat mass, with, on the counterpart, only marginal differences for midthigh and calf measurements ( $₫ 0.08, \mathrm{p}<0.0005)$.

DXA is a useful instrument also to assess body composition changes associated with aging. As for FFM, hydration level can affect DXA estimates of fat tissue (81) but to a lesser extent than FFM. It has been shown that an increase or a decrease in hydration levels of $5 \%$ biases DXA estimates of percent fat only 1.5 to $2.5 \%(73,78,82,83)$.

Regional body composition with DXA is considered somewhat less precise than total body fat assessment. Kietzbak et al (84) found that regional measurements (arm, leg, trunk and pelvis) were less precise with CVs of $1 \%$ to $3 \%$ for total body, $4.3 \%$ for fat mass for arms and $3.1 \%$ for trunk. Going (85) assessed abdominal fat by DXA at L2-L4 combined with and abdominal skinfold thickness and found higher correlation between DXA estimated abdominal adipose tissue and truncal skinfold than for extremity skinfold thickness, reporting high precision for this technique. Svendsen et al (86) performed a comparison between DXA abdominal fat, in combination with skinfold thickness and abdominal fat measured with CT. They observed that DXA measurements accounted for $80 \%$ of the variance in intra abdominal fat as evaluated by $\mathrm{CT}$ and the combination of abdominal fat measured with DXA and skinfold thickness accounted for $91 \%$ with a $\mathrm{CV}=14.8 \%$.

Limb composition measures from DXA have been previously validated by Heymsfield et al (59) comparing DXA estimates extremity muscle mass with total body potassium and nitrogen. These results have been confirmed by Kim (87) and Baumgartner (88).

\section{Air displacement plethysmography}

ADP by Bod Pod measures body volume and body density.

Estimates of body composition by the Bod Pod have been validated against hydrodensitometry and DXA (89). However most of the studies using Bod Pod to evaluate FM have been performed in adults, except the study of Nunez et al (90) that included subjects up to 86 years of age.

The results of studies comparing body composition measurements by DXA and Bod Pod in adults showed differences between the two methods in percent of body fat varying between $-3.0 \%$ to $1.7 \%$ fat $(90-93)$.

In adults, Koda (92) showed an overall difference of $-0.1 \%$ fat with a significant negative mean difference for females $(-1.3 \%)$ and a significant positive mean difference for males (1.2\%). the $95 \%$ limits of agreement ranged form $10 \%$ to $15 \%$ in three studies reporting Bland and Altman analyses (93-95) indicating large differences between DXA and Bod Pod in some individuals.

\section{Echography}

Ultrasound has been used to measure thickness of SAT, muscle and intra-abdominal fat, measurement quality depends on the acoustic impedence properties of different tissue 
interfaces traversed. A fat-muscle interface produces a weaker echo than fat-bone or musclebone interface. Dynamic cross-sectional images on the monitor can be frozen allowing measurements with electronic callipers to the nearest $1 \mathrm{~mm}$ and images can be saved for future reference. Ultrasonic scanning is a procedure relatively simple and reliable as far as subcutaneous adipose tissue in concerned. It becomes operator-dependent when measuring intra-abdominal adipose tissue.

When considering different subcutaneous sites the validity of measurements with ultrasound is uncertain (96) with intraobserver coefficient of reliability varying from 86 to $97 \%$ and interobserver coefficient of reliability varying from 81 to $98 \%$. Other studies confirmed that ultrasound measurements of subcutaneous adipose tissue at abdominal level is reliable and this measurement was also validated by direct measurement during surgical procedures. Furthermore it has been used in predictive formulas for total adipose tissue mass measured by multislice CT method $(97,98)$. B-mode ultrasound was shown to be superior compared to the measurements of skinfold thickness,

The disadvantages of ultrasound, in comparison with calipers, are its greater expense and lesser portability, although portable equipment is also available.

\section{Imaging methods}

Computed tomography-CT has been used to measure total body fat content and distribution, giving accurate measurement of visceral and subcutaneous fat depots (99).

Attenuation is related to tissue density and chemical composition. CT can visualize adipose tissue and with the help of software, it can quantify adipose tissue on cross-sectional images. Fat in adipose tissue, skeletal muscle, bone, visceral organs and brain can also be measured (100). In serial scans, the body fat measurement can be made with a margin of error of less than $1 \%$. CT involves radiation exposure, a major drawback in application for body composition analysis in routine clinical care. If less radiation exposure is desired, a single slice measurement can be made. Visceral adipose tissue and subcutaneous adipose tissue are usually measured at the L2-L3 and L4-L5 disc spaces (101) and has been shown to correlated with total intra-abdominal adipose tissue.

MRI-MRI has been proposed as an alternative technique for determining visceral and subcutaneous body fat at the thoracic and abdominal level (Figure 5). It has been validated in phantoms, animals, and human cadavers and has been shown to accurately measure adipose tissue in vivo, showing good agreement with values produced by dissection and chemical analysis (102-105). Furthermore, it has been shown that MRI can be used serially to measure different body fat depots in human subjects $(104,106,107)$. However, a review of published literature shows that a wide variety of methodologies has been used, with different MRI parameters and methods of data collection, ranging from extrapolation of single-slice acquisitions (108) or multiple-slice acquisitions over selected regions of the body $(104,107,109,110)$ to whole body fat measurements (106). Single or spatially limited multiple-slice acquisitions, as opposed to whole body data sets, have been used as a compromise between accuracy and cost, including scanning and/or analysis time. 
MRI requires a closed magnetic area and a relatively longer time for measurement than CT. Although the two imaging modalities are completely different in technique, measurements of visceral fat and subcutaneous fat by the two instruments showed good agreement. MRI has been used in the determination of quantity and distribution of fat and muscular tissue. MRI can measure the volume of subcutaneous, intra-abdominal, visceral and intramuscular adipose tissue. There is no X-ray exposure, making this method conveniently applicable to children and adolescents (111). In standard T1-weighted images, fatty septas are seen in muscles. Low levels of muscle lipid content cannot be evaluated in T1-weighted series. However, in imaging carried out with selective high lipid signals, the muscular areas with high quality fat content are determined (112). Conventional MRI is not useful for assessment of lipid and water quantity in skeletal muscle (113). Chemical shift imaging methods have been used to differentiate water and fat signals in MRI, enabling to quantify water and fat contents of skeletal muscle [16]. It is possible to perform whole body MRI to determine body composition and to assess the effect of weight loss treatment on body fat distribution and quantity (111).

\section{Methods for ectopic fat deposition evaluation in muscle (myosteatosis)}

Ectopic fat deposition inside muscle has been described to increase with aging and with obesity (114). As anthropometry, BIA and DXA cannot detect the presence of fat inside muscles; more sophisticated methods such as CT scan and MRI are needed for its evaluation.

The average HU for fat free skeletal muscle voxels can be used as an index of skeletal muscle lipid content (Figure 2). The lower the skeletal muscle HU value, corresponding to mean muscle attenuation, the higher the skeletal muscle lipid content. Muscle attenuation however must be considered a reflection of both intramyocellular and extramyocellular lipid content, not only intramyocellular that can be measured only with biopsy or proton magnetic resonance spectroscopy. As the attenuation value of fat is negative and muscle is positive, the lipid increase in muscular tissue decreases the attenuation of the muscle. Increased muscle lipid content in muscle both chemically and histochemically can be detected in obesity and type 2 diabetes mellitus (112). Low muscular attenuation values were found to be associated with decrease in muscular strength, low physical activity, insulin resistance and obesity in aged women and men (115). Standard T1 weighted MR images provide visualization of fatty septa between skeletal muscle bundles and beneath the muscle fascia, recently called intermuscular adipose tissue (IMAT). Rossi et al confirmed with intraoperative biopsy sample in 18 healthy elderly men and women, undergoing elective vertebral surgery, that IMAT as evaluated by MRI is a valid method for assessing intermuscular adipose tissue (116). Changing the threshold between muscle and IMAT to $10 \%$ of the reference of the surrounding SAT, authors observed an improvement of the agreement between MRI and histological evaluation.

However it must be considered that small concentration of lipid within muscle tissue cannot be assessed with standard T1 weighted images, but require fat selective images (117).

MRS is a new non invasive method and can measure the fat tissue content and distribution both in adipose tissue and in non-adipose tissue (112). The lipid content of the skeletal 
muscle can be measured with MRS (118).Volume localized magnetic resonance spectroscopy is a recently developed method and the intra-myocellular and extramyocellular lipid differentiation can be made in vivo. Intramyocellular lipid levels can be quantified by 1H-MRS (119).

The differentiation of these two lipid components can be made with the differentiation of lipid-CH2-regions with resonance. This method was used to explore the relation between intra-myocellular lipid and insulin resistance and the influence of exercise on intramyocellular lipid content (120).

The margin of error in this method is $6 \%$ in the assessment of intra-myocellular lipid content (119).

\section{List of abbreviation}

$\begin{array}{ll}\text { FM } & \text { fat mass } \\ \text { FFM } & \text { fat-free mass } \\ \text { BMI } & \text { body mass index } \\ \text { LST } & \text { lean soft tissue } \\ \text { TBW } & \text { total body water } \\ \text { BMC } & \text { bone mineral content } \\ \text { WHR } & \text { waist hip ratio } \\ \text { MRI } & \text { magnetic resonance imaging } \\ \text { CT } & \text { computer tomography } \\ \text { CV } & \text { coefficient of variation } \\ \text { IMAT } & \text { intermusuclar adipose tissue } \\ \text { VAT } & \text { visceral adipose tissue } \\ \text { SCAT } & \text { subcutaneous adipose tissue } \\ \text { SAD } & \text { sagittal abdominal diameter } \\ \text { OR } & \text { odds ratio }\end{array}$

\section{REFERENCES}

1. Baumgartner RN, Stauber McHugh D, et al. Cross-sectional age differences in bpdy composition in persons 60+ years of age. J Gerontol Med Sci. 1995; 50A:M307-M316.

2. Hughes VA, Frontera WR, Roubenoff R, Evans WJ, Singh MA. Longitudinal changes in body composition in older men and women: role of body weight change and physical activity. Am J Clin Nutr. 2002; 76:473-481. [PubMed: 12145025]

3. Lissner L, Sjostrom L, Bengtsson C, Bouchard C, Larsson B. the natural history of obesity in an obese population and association with metabolic aberrations. Int J Obes Relat Metab Disord. 1994; 18:441-447. [PubMed: 8081436]

4. Prentice AM, Jebb SA. Beyond body mass index. Obes Rev. 2001; 2:141-147. [PubMed: 12120099] 
5. Noppa H, Andersson M, Bengtsson C, Bruce A, Isaksson B. Body compostion in middle-aged women with special reference to the correlation between body fat mass and anthropometric data. Am J CLin Nutr. 1979; 32:1388-1395. [PubMed: 110127]

6. Janssen I, Heymsfield SB, Ross R. Low relative skeletal muscle mass (sarcopenia) in older persons is associated with functional impairment and physical disability. J Am Geriatr Soc. 2002

7. Goodpaster BH, Carlson CL, Visser M, Kelley DE, Scherzinger A, Harris TB, Stamm E, Newman AB. Attenuation of skeletal muscle and strength in the elderly. J Appl Physiol. 2001; 90:2157-2165. [PubMed: 11356778]

8. Visser M, Langlois J, Guralnik JM, et al. High body fatness, but not low fat-free mass, predicts disability in older men and women: the Cardiovascular Health Study. Am J Clin Nutr. 1998; 68:584-590. [PubMed: 9734734]

9. Broadwin J, Goodman-Gruen D, Slymen D. Ability of fat and fat-free mass percentages to predict functional disability in older men and women. J Am Geriatr Soc. 2001; 49:1641-1645. 50:889-896.14. [PubMed: 11843997]

10. Baumgartner RN. Body composition in healthy aging. Ann NY Acad Sc. 2000; 904:437-448. [PubMed: 10865787]

11. Villareal DT, Banks M, Siener C, Sinacore DR, Klein S. Physical frailty and body composition in obese elderly men and women. Obes Res. 2004; 12:913-920. [PubMed: 15229329]

12. Sternfeld B, Ngo L, Satariano WA, Tager IB. Associations of body composition with physical performance and self-reported functional limitation in elderly men and women. Am J Epidemiol. 2002; 156:110-121. [PubMed: 12117699]

13. Fantin F, Di Francesco V, Fontana G, Zivelonghi A, Bissoli L, Zoico E, Rossi A, Micciolo R, Bosello O, Zamboni M. longitudinal body composition changes in old men and women: interrealtionships with worsening disability. J Gerontol A Biol Sci Med Sci. 2007; 62:1375-1381. [PubMed: 18166688]

14. Ramsey SE, whincup PH, shaper AG, Wannamethee SG. the relations of body composition and adiposity measures to ill health and physical disability in elderly men. Am J Epidemiol. 2006; 164:459-469. [PubMed: 16818465]

15. Zoico E, Di Francesco V, Guralnik JM, et al. Physical disability and muscular strength in relation to obesity and different body composition indexes in a sample of healthy elderly women. Int $\mathrm{J}$ Obes Relat Metab Disord. 2004; 28:234-241. [PubMed: 14708033]

16. Lee JS, Kritchevsky SB, Tylavsky F, et al. Weight change, weight change intention, and the incidence of mobility limitation in well-functioning community-dwelling older adults. J Gerontol A Biol Sci Med Sci. 2005; 60:1007-1012. 10. [PubMed: 16127104]

17. Apovian CM, Frey CM, Wood CG, et al. Body mass index and physical function in older women. Obes Res. 2002; 10:740-747. [PubMed: 12181382]

18. Launer LJ, Harris T, Rumpel C, Madans J. Body mass index, weight change, and risk of mobility disability in middle-aged and older women: the Epidemiologic Follow-up Study of NHANES I. JAMA. 1994; 271:1093-1098. [PubMed: 8151851]

19. Jensen GL, Friedmann JM. Obesity is associated with functional decline in community-dwelling rural older persons. J Am Geriatr Soc. 2002; 50:918-923. [PubMed: 12028181]

20. Houston KD. Stevens J Cai J Abdominal fat distribution and functional limitations and disability in a biracial cohort: the Atherosclerosis Risk in Communities Study.

21. Ensrud KE, Nevitt MC, Yunis C, Cauley JA, Seeley DG, Fox KM, Cummings SR. Correlates of impaired function in older women. J Am Geriatr Soc. 1994; 42:481-489. [PubMed: 8176141]

22. Chen H, Bermudez OI, Tucker KL. Waist circumference and weight change are associated with disability among elderly Hispanics. J Gerontol. 2002; 57A:M19-M25.

23. Visser M, Goodpaster BH, Kritchevsky SB, et al. Muscle mass, muscle strength, and muscle fat infiltration as predictors of incident mobility limitations in well-functioning older persons. J Gerontol A Biol Sci Med Sci. 2005; 60:324-333. [PubMed: 15860469]

24. Visser M, Kritchevsky SB, Goodpaster BH, et al. Leg muscle mass and composition in relation to lower extremity performance in men and women aged 70 to 79 : the health, aging and body composition study. J Am Geriatr Soc. 2002; 50:897-904. [PubMed: 12028178] 
25. Zamboni M, Mazzali G, Fantin F, Rossi A, Di Francesco V. Nutr Metab Cardiovasc Dis. 2008; 18:388-395. [PubMed: 18395429]

26. Brozek J, Grande F, Anderson JT, Keys A. Densitometric analysis of body composition: Revision of some quantitative assumptions. Ann NY Acad Sci. 1963; 110:113-140. [PubMed: 14062375]

27. Brozek J, Keys A. Relatiive body weight, age and fatness. Geriatrics. 1953; 8:70-75. [PubMed: 13034042]

28. Pierson, RN. Quality of the body cell mass. New York: Springer; 2000.

29. Heymsfield, SB.; Lichtman, s; Baumgartner, RN.; Dilmanian, FA.; Kamen, Y. Assessment of body composition: an overview. In: Bjorntorp, P., editor. Obesity. New York: JB Lippincott; 1992. p. 37-54.

30. Snyder, Ws; Cook, MJ.; Nasset, ES. Report of the task group on reference man. Elmsford NY: Pergamon press; 1975.

31. Heymsfiled BS, Lohman TG, Wang Z, Going SB. Human body composition. 14:203-204.

32. Heymsfiled SB, Olafson RP, Kutner MH, Nixon DW. A radiographic method of quantifiying protein-calorie undernutrition. Am J Clin Nutr. 1979; 32:693-702. [PubMed: 105625]

33. Lee RC, Wang Z, Heo M, Ross R, Janssen I, Heymsfield SB. Total body skeletal muscle mass: development and cross-validation of anthropometric prediction models. Am J Clin Nutr. 2000; 72:796-803. [PubMed: 10966902]

34. Heymsfield SB, McManus C, Stevens C, Smith J. Muscle mass: reliable indicator of proteinenergy malnutrition severity and outcome. Am J Clin Nutr. 1982; 35:1192-1199. [PubMed: 6805298]

35. Roubenoff R, Kehayias J, Rosemberg IH, Heymsfiled SB, Cannon JG. Standardization of nomenclature of body composition in weight loss. Am J Clin Nutr. 1997; 66:192-196. [PubMed: 9209192]

36. Kyle UG, Bosaeus I, De Lorenzo AD, et al. Bioelectrical impedance analysis-part II: utilization in clinical practice Clinical Nutrition. 2004; 23:1430-1453.

37. Janssen I, Heymsfield SB, Baumgartner RN, Ross R. Estimation of skeletal muscle mass by bioelectrical impedance analysis. Journal of Applied Physiology. 2000; 89(2):465-471. [PubMed: 10926627]

38. Bioelectrical impedance analysis in body composition measurement: National Institutes of Health Technology Assessment Conference Statement. Am J Clin Nutr. 1996 Sep; 64(3 Suppl):524S532S. [PubMed: 8780375]

39. Deurenberg P, Deurenberg-Yap M. Validity of body composition methods across ethnic population groups. Acta Diabetol. 2003; 40(Suppl. 1):S246-S249. [PubMed: 14618484]

40. Deurenberg P, Kooy K, Paling A, Withagen P. Assessment of body composition in 8-11 year old children by bioelectrical impedance. Eur J Clin Nutr. 1989; 43:623-629. [PubMed: 2606093]

41. Broekhoff C, Voorrips LE, weijenberg MP, Witvoet GA, van Staveren WA, Deurenberg P. Ann Nutr Metab. 1992; 36:148-156. [PubMed: 1530283]

42. Deurenberg P, Kusters CSL, Smith HE. Assessment of body composition by bioelectrical impedance in children and young adults is strongly age-dependent. Am J Clin Nutr. 1990; 44:261268.

43. Baumgartner RN, Heymsfield SB, Lichtman S, Wang J, Pierson RN jr. Am J Clin Nutr. 1991; 53:1345-1353. [PubMed: 2035461]

44. Roubenoff R, Baumgartner RN, Harris TB, Dallal GE, Hannan MT, Economos CD, Stauber PM, Wilson PW, Kiel DP. Application of bioelectrical impedance analysis to elderly population. J Gerontol A Biol Sci Med Sci. 1997; 52:M129-M136. [PubMed: 9158553]

45. Forbes G, Simon W, Amatruda J. Is bioimpedance a good predictor of body composition change. Am J Clin Nutr. 1992; 56:4-6. [PubMed: 1609759]

46. Kellie SE. Measurement of bone density with dual-energy x-ray absorptiometry (DXA). J Am Med Ass. 1992; 267:286-294.

47. Lohman TG, harris TB, teixeira PJ, Weiss L. Assessing body composition and changes in body composition. Another look at dual-energy x-ray absorptiometry. Ann NY Acad Sci. 2000; 904:4554. [PubMed: 10865709] 
48. Wang ZM, Visser, Ma R, Baumgartner RN, Kotler D, Gallagher D, Heymsfield SB. Skeletal muscle mass: evaluation of neutron activation and dual-energy X-ray absorptiometry methods. J Appl Physiol. 1996; 80:324-331.

49. Nord RH. Evaluation of a new instrument for measuring body composition. Ann NY Med Acc Sci. 2000; 904:118-125.

50. Visser M, Fuerst T, Lang T, Salamone L, Harris TB. Validity of fan-beam dual-energy X-ray absorptiometry for measuring fat-free mass and leg muscle mass. Health, Aging, and body ccompositon working group. J Appl Physiol. 1999; 87:1513-1520. [PubMed: 10517786]

51. Clark RR, Bartok C, Sullivan JC, Schoeller DA. Minimum weight prediction methods crossvalidated by four-component model. Med Sci Sport Exerc. 2004; 36:639-647.

52. Tylavsky FA, Lohman TG, Dockrell M, Lang T, Schoeller DA, Wan JY, Fuerst T, Cauley JA, Nevitt M, Harris TB. Am J Clin Nutr. 2003; 77:356-363. [PubMed: 12540394]

53. Genton L, Hans D, Kyle UG, Pichard C. Dual energy X-ray absorptiometry and body composition: differences between devices and comparison with reference methods. Nutrition. 2002; 18:66-70. [PubMed: 11827768]

54. Ellis KJ, Shypailo RJ. Bone mineral and body composition measurements: cross-calibration of pencil-beam and fan-beam dual-energy X-ray absorptiometers. J Bone Min Res. 1998; 13:16131618.

55. Cordero-MacIntyre ZR, Peters W, Libanati CR, Espana RC, Abila SO, Howell WH, Lohman TG. Reproducibility of DXA in obese women. J Clin Densitom. 2002; 5:35-44. [PubMed: 11940727]

56. Clark RR, Bartok C, Sullivan JC, Schoeller DA. Minimum weight prediction methods crossvalidated by four-component model. Med Sci Sport Exerc. 2004; 36:639-647.

57. Tothill P, Laskey MA, Orphanidou CI, van Wijk M. Anomailes in dual energy X-ray absorptiometry measurements of total-body bone mineral during weight change using Luner, Hologic and Norland instruments. Br J Radiol. 1999; 72:661-669. [PubMed: 10624323]

58. Tothill P, Hannan WJ. Comparson between Hologic QDR 1000W, QDR 4500A, and Luner Expert dual energy X-ray absorptiometry scanners used for measuring total body bone and soft tissue. Ann N Y Acad Sci. 2000; 904:63-71. [PubMed: 10865711]

59. Heymsfield SB, Smith R, Aulet M, et al. Appendicular skeletal muscle mass: measurement by dual photon absorptiometry. Am J Clin Nutr. 1990; 52:214-218. [PubMed: 2375286]

60. Horber FF, Thomi F, Casez JP, Fonteille J, Jaeger P. Impact of hydratation status on body composition as measured by dual energy $\mathrm{X}$-ray absorptiometry in normal volunteers and patients on haemodialysis. Br J Radiol. 1992; 65:895-900. [PubMed: 1422663]

61. Levitt DG, Beckman LM, Mager JR. Comparison of DXA and water measurements of body fat following gastric bypass surgery and a physiological model of body water, fat, and muscle composition. J Appl Physiol. 2010 Sep; 109(3):786-795. [PubMed: 20558754]

62. Sjostrom L. A computer-tomography based multicompartment body composition technique and anthropometric prediction of lean body mass, total and subcutaneous adipose tissue. Int J Obes. 1991; 15(Suppl 2):19-30. [PubMed: 1794934]

63. Goodpaster BH, Thaete FL, Simoneau JA, Kelley DE. Subcutaneous abdominal fat and thigh muscle composition predicts insulin sensitivity independently of visceral fat. Diabetes. 1997; 46:1579-1585. [PubMed: 9313753]

64. Wang ZM, Elan R, Ma R, Matthews D, Nelson M, et al. Validation of indirect skeletal muscle mass methods by computer axial tomography. Federation of American Societies for Experimental biology. 1993; 7:A83. abstarct 477.

65. Hudash G, Albright JP, McAuley E, Martin RK, Fulton M. Med Sci Sport Exerc. 1985; 17:417421.

66. Borkan GA, Hults DE, Gerzof SG, Robbins AH, Silbert CK. Age changes in body composition revealed by computed tomography. J Gerontol. 1983; 38:673-677. [PubMed: 6630900]

67. Goodpaster BH, Park SW, Harris TB, et al. The loss of skeletal muscle strength, mass, and quality in older adults: the health, aging and body composition study. J Gerontol A Biol Sci Med Sci. 2006; 61:1059-1064. [PubMed: 17077199]

68. Fiatarone MA, Marks EC, Ryan ND, Meredith CN, Lipsitz LA, Evans WJ. JAMA. 1990; 263:3029-3034. [PubMed: 2342214] 
69. Dube JJ, Goodpaster BH. Assessment of intramuscular triglycerides: contribution to metabolic abnormalities. Curr Opin Clin Nutr Met Care. 2006; 9:553-559.

70. Ross R, Shaw KD, Rissanen J, Martel Y, de Guise J, Avruch L. Am J Clin Nutr. 1994; 59:12771285. [PubMed: 8198051]

71. Ross R, Leger L, Morris D, De Guise J, Guardo R. Quantification of adipose tissue by MRI: relationship with anthropometric variables. J Appl Physiol. 1992; 72:787-795. [PubMed: 1559959]

72. Mitsiopoulos N, Baumgartner RN, Heymsfield SB, Lyons W, Gallagher D, Ross R. Cadaver validation of skeletal muscle measurements by magnetic resonance imaging and computer tomography. J appl Physiol. 1998; 85:115-122. [PubMed: 9655763]

73. Wang Z, Pi-Sunyer FX, Kotler DP, Weilopolski L, Withers RT, Pierson RN Jr, Heymsfield SB. Am J Clin Nutr. 2002; 76:968-974. [PubMed: 12399267]

74. Chumlea WC, Guo SS, Kuczmarsky RJ, et al. Body composition estimates form NHANES III bioelectrical impedance data. Int J Obes. 2002; 26:1596-1611.

75. lohman . 1991

76. Lohman TG. Skinfold and body density and their relation to body fatness: a review. Hum Biol. 1981; 53:181-225. [PubMed: 7239496]

77. Lohman TG, Harris M, Teixeira PJ, Weiss L. Assessing body composition and changes in body composition. Another look at dual-energy X-ray absorptiometry. Ann N Y Acad Sci. 2000; 904:45-54. [PubMed: 10865709]

78. Evans EM, Saunders MJ, Spano MA, Amgrimsson SA, Lewis RD, Cureton KJ. Body- composition changes with diet and exercise in obese women: a comparison of estimates form clinical methods and a 4-component model. Am J Clin Nutr. 1999; 70:5-12. [PubMed: 10393132]

79. Kohrt WM. Perliminary evidence that DXA provides an accurate assessment of body composition. J Appl Physiol. 1998; 84:372-377. [PubMed: 9451659]

80. Salamone LM, fuerst T, visser M, Kern M, Lang T, Dockrell M, Tylavsky F, Lohman TG. Measurement of fat mass using DXA: a validation study in elderly adults. J Appl Physiol. 2000; 904:45-54.

81. Roubenoff R, Kehayias JJ, Dawson-Hughes B, Heymsfield SB. use of dual-energy X-ray absorptiometry in body-composition studies: not yet a "gold standard". Am J Clin Nutr. 1993; 58:5898-5891.

82. Pietrobelli A, Formica C, Wang Z, Heymsfield SB. Dual-energy X-ray absorptiometry body composition model: review of physical concepts. Am J Physiol. 1996; 271:E941-E951. [PubMed: 8997211]

83. Going SB, Massett MP, Hall MC, Bare LA, Root PA, Williams DP, Lohman TG. Detecction of small changes in body compostino by dual Energy X-ray absorptiometry. Am J Clin Nutr. 1993; 57:845-850. [PubMed: 8503351]

84. Kietzbak GM, Leamy LJ, Pierson LM, Nord RH, Zhang ZY. Measurement precision of body composition variables using the Lunar DPX-L densitometer. J Clin Denstiom. 2000; 3:35-41.

85. Going SB, Massett MP, Hall MC, Bare LA, Root PA, Williams DP, Lohman TG. 1990

86. Svendsen OL, Hassager C, Bergmann I, Christiansen C. Measureement of abdominal and intrabdominal fat in postmenopausal women with dual nergy X-ray absorptiometry: comparison with computer tomography. Int J Obes Relat Metab Disord. 1993; 17:45-51. [PubMed: 8383641]

87. Kim . 2002

88. Baumgartner RN, Koehler KM, Gallagher D, Romero L, Heymsfield SB, Ross RR, Garry PJ, Lindeman RD. Epidemiology of sarcopenia among the elderly in New Mexico. Am J Epidem. $1998 ; 147: 755-763$.

89. Demerath EW, Guo SS, Chumlea WC, Towne B, Roche AF, Siervogel RM. Comparison of percent body fat estimates using air displacement plethysmography and hydrodensitometry in adults and children. Int J Obes Relat Metab Disord. 2002; 26:389-397. [PubMed: 11896495]

90. Nunez C, Kovera AJ, Pietrobelli A, Heshka S, Horlick M, Kehayias JJ, Wang Z, Heymsfield SB. Body composition in children and adults by air displacement plethysmography. Eur J Clin Nutr. 1999; 53:382-387. [PubMed: 10369494] 
91. Collins MA, Millard-Stafford ML, Sparling PB, Snow TK, Rosskopf LB, Webb SA, Omer J. Evaluation of the BOD POD for assessing body fat in collegiate football players. Med Sci Sports Exerc. 1999; 31:1350-1356. [PubMed: 10487380]

92. Koda M, Tsuzuku S, Ando F, Niino N, Shimokata H. Body composition by air displacement plethysmography in middle-aged and elderly Japanese. Comparison with dual-energy X-ray absorptiometry. Ann N Y Acad Sci. 2000; 904:484-488. [PubMed: 10865792]

93. Fields DA, Goran MI, McCrory MA. Body composition assessment via air-displacement plethysmography in adults and children: a review. Am J Clin Nutr. 2002; 75:453-467. [PubMed: 11864850]

94. Levenhagen DK, Borel MJ, Welch DC, Piasecki JH, Piasecki DP, Chen KY, Flakoll PJ. A comparison of air displacement plethysmography with three other techniques to determine body fat in healthy adults. J Parenter Enteral Nutr. 1999; 23:293-299.

95. Sardinha LB, Lohman TG, Teixeira PJ, Guedes DP, Going SB. Comparison of air displacement plethysmography with dual-energy X-ray absorptiometry and 3 field methods for estimating body composition in middle-aged men. Am J Clin Nutr. 1998; 68:786-793. [PubMed: 9771855]

96. Bellisari A, Roche AF, Siervogel RM. Reliability of B-mode ultrasonic measurements of subcutaneous adipose tissue and intra-abdominal depth: comparison with skinfold thicknesses. Int J Obes Relat Metab Disord. 1993; 17:475-480. [PubMed: 8401751]

97. Armellini F, Zamboni M, Robbi R, Todesco T, Rigo L, Bergamo-Andreis IA, Bosello O. Total and intra-abdominal fat measurements by ultrasoubd and computer tomography. Int J Obes Relat Metab Disord. 1993; 17:209-214. [PubMed: 8387970]

98. Armellini F, Zamboni M, Castelli S, Micciolo R, Mino A, Turcato E, Rigo L, Bergamo-Andreis IA, Bosello O. Measured and predicted total and visceral adipose tissue in women. Correlations with metabolic parameters. Int J Obes Relat Metab Disord. 1994; 18:641-647. [PubMed: 7812419]

99. Sjohstrom L. A computer tomography based multicompartment body composition technique and anthropometric predictions of lean body mass, total and subcutaneous adipose tissue. Int. J. Obes. 1991; 5(Suppl. 2):19S-30S.

100. Mattsson S, Thomas BJ. Development of methods for body composition studies. Phys Med Biol. 2006; 51:R203-R228. [PubMed: 16790904]

101. Bray GA, Jablonski KA, Fujimoto WY, et al. Relation of central adiposity and body mass index to the development of diabetes in the Diabetes Prevention Program. Am J Clin Nutr. 2008; 87:1212-1218. [PubMed: 18469241]

102. Abate N, Burns D, Peshock RM, Garg A, Grundy SM. Estimation of adipose tissue mass by magnetic resonance imaging: validation against dissection in human cadavers. J. Lipid Res. 1994; 35:1490-1496. [PubMed: 7989873]

103. Fowler PA, Fuller MF, Glasbey CA, Cameron GG, Foster MA. Validation of the in vivo measurement of adipose tissue by magnetic resonance imaging of lean and obese pigs. Am. J. Clin. Nutr. 1992; 56:7-13. [PubMed: 1609764]

104. Fowler PA, Fuller MF, Glasbey CA, Foster MA, Cameron GG, McNeill G, Maughan RJ. Total and subcutaneous adipose tissue in women: the measurement of distribution and accurate prediction of quantity by using magnetic resonance imaging. Am. J. Clin. Nutr. 1991; 54:18-25. [PubMed: 2058582]

105. Ross R, Léger L, Guardor R, DeGuise J, Pike BG. Adipose tissue volume measured by magnetic resonance imaging and computerized tomography in rats. J. Appl. Physiol. 1991; 70:2164-2172. [PubMed: 1864799]

106. Ross R, Kimberley DS, Martel Y, De Guise J, Avruch L. Adipose tissue distribution measured by magnetic resonance imaging in obese women. Am. J. Clin. Nutr. 1993; 57:470-475. [PubMed: 8460599]

107. Sohlström A, Wahlund LO, Forsum E. Adipose tissue distribution as assessed by magnetic resonance imaging and total body fat by magnetic resonance imaging, underwater weighing and body-water dilution in healthy women. Am. J. Clin. Nutr. 1993; 58:830-838. [PubMed: 8249863] 
108. Abate N, Garg A, Coleman R, Grundyn SM, Peshock RM. Prediction of total subcutaneous abdominal, intraperitoneal, and retroperitoneal adipose tissue masses in men by a single axial magnetic resonance imaging slice. Am. J. Clin. Nutr. 1997; 65:403-408. [PubMed: 9022523]

109. Staten MA, Totty WG, Kohrt WM. Measurement of fat distribution by magnetic resonance imaging. Invest. Radiol. 1989; 24:345-349. [PubMed: 2745015]

110. Tothill P, Han TS, Avenell A, McNeill G, Reid DM. Comparisons between fat measurements by dual-energy X-ray absorptiometry, underwater weighing and magnetic resonance imaging in healthy women. Eur. J. Clin. Nutr. 1996; 50:747-752. [PubMed: 8933122]

111. Mattsson S, Thomas BJ. Development of methods for body composition studies. Phys Med Biol. 2006; 51:R203-28. [PubMed: 16790904]

112. Goodpaster BH. Measuring body fat distribution and content in humans. Curr Opin Clin Nutr Metab Care. 2002; 5:481-487. [PubMed: 12172470]

113. Lee SY, Gallagher D. Assessment methods in human body composition. Curr Opin Clin Nutr Metab Care. 2008; 11:566-572. [PubMed: 18685451]

114. Goodpaster BH, Krishnaswami S, Harris TB, et al. Obesity, regional body fat distribution, and the metabolic syndrome in older men and women. Arch Intern Med. 2005; 165(7):777-783. [PubMed: 15824297]

115. Goodpaster BH, Kelley DE, Thaete FL, He J, Ross R. Skeletal muscle attenuation determined by computed tomography is associated with skeletal muscle lipid content. J Appl Physiol. 2000; 89:104-110. [PubMed: 10904041]

116. Rossi AP, Zoico E, Goodpaster BH, et al. Quantification of intermuscular adipose tissue in the erector spinae muscle by MRI: agreement with histological evaluation of lipid. Obesity. 2010

117. Machann J, Bachmann OP, Brechtel K, Dahl DB, Wietek B, Klumpp B, Häring H-U, Claussen $\mathrm{CD}$, Jacob S, Schick F. Lipid content in the musculature of the lower leg assessed by fat selective MRI: Intra- and interindividual differences and correlation with anthropometric and metabolic data. J. Magn. Reson. Imaging. 2003; 17:350-357. [PubMed: 12594726]

118. Lee SY, Gallagher D. Assessment methods in human body composition. Curr Opin Clin Nutr Metab Care. 2008; 11:566-572. [PubMed: 18685451]

119. Boesch C, Slotboom J, Hoppeler H, Kreis R. In vivo determination of intra-myocellular lipids in human muscle by means of localized 1H-MR-spectroscopy. Magn Reson Med. 1997; 37:484493. [PubMed: 9094069]

120. White LJ, Ferguson MA, McCoy SC, Kim H. Intramyocellular lipid changes in men and women during aerobic exercise: a (1)Hmagnetic resonance spectroscopy study. J Clin Endocrinol Metab. 2003; 88:5638-5643. [PubMed: 14671146] 


\section{Dual Energy X-ray Absorbiometry}

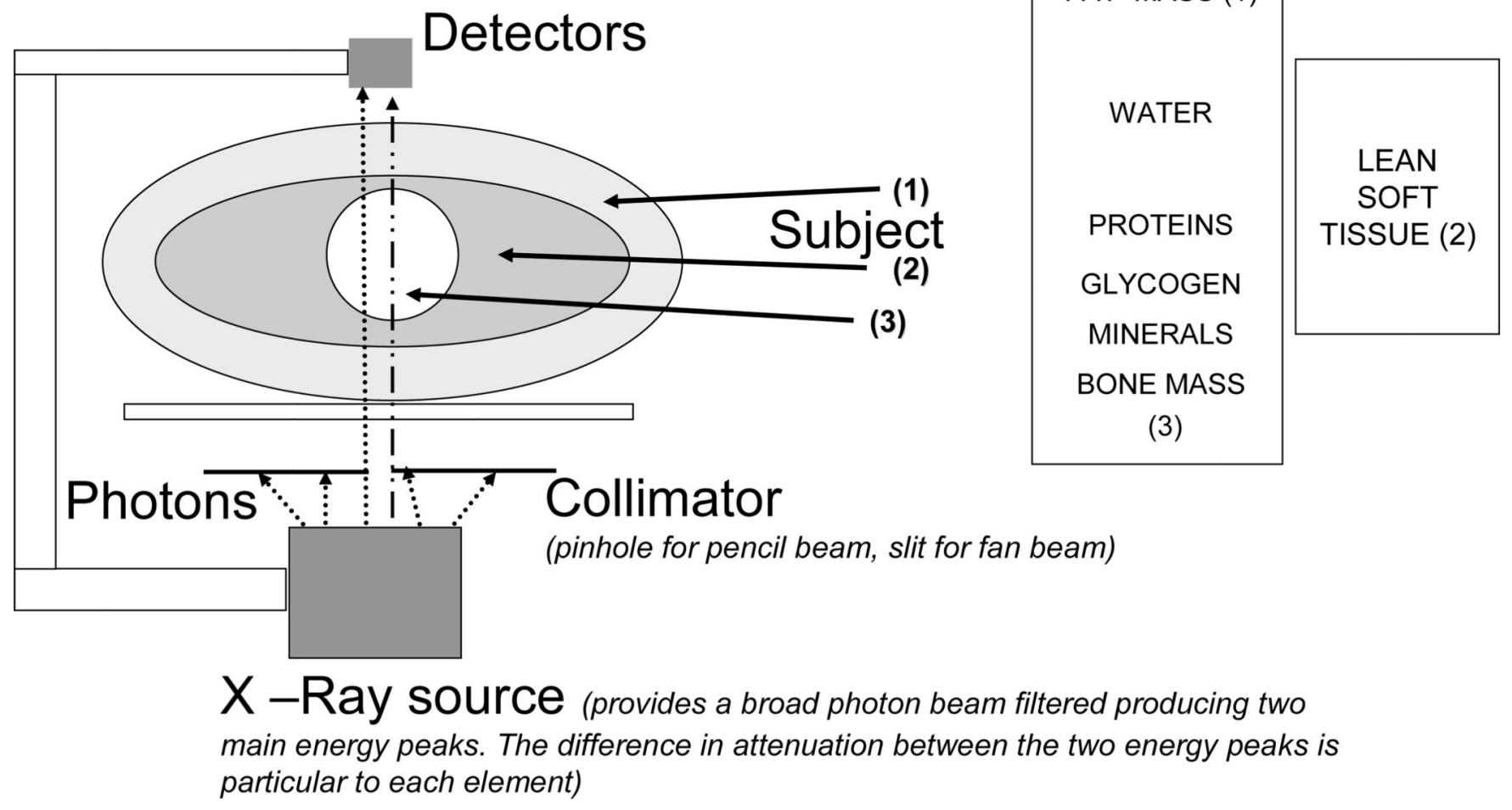

Figure 1. Dual Energy X-ray Absorbiometry (DXA)

The person lays on the whole body scanner, with the X-ray sources mounted beneath a table and a detector overhead. The person is scanned with photons that are generated by two lowdose x-rays at different energy levels. The body's absorption of the photons at the two levels is measured. The ratios $(\mathrm{R})$ can be then used to predict total body fat, fat-free mass, and total body bone mineral. The procedure can take about $5-10$ minutes. 


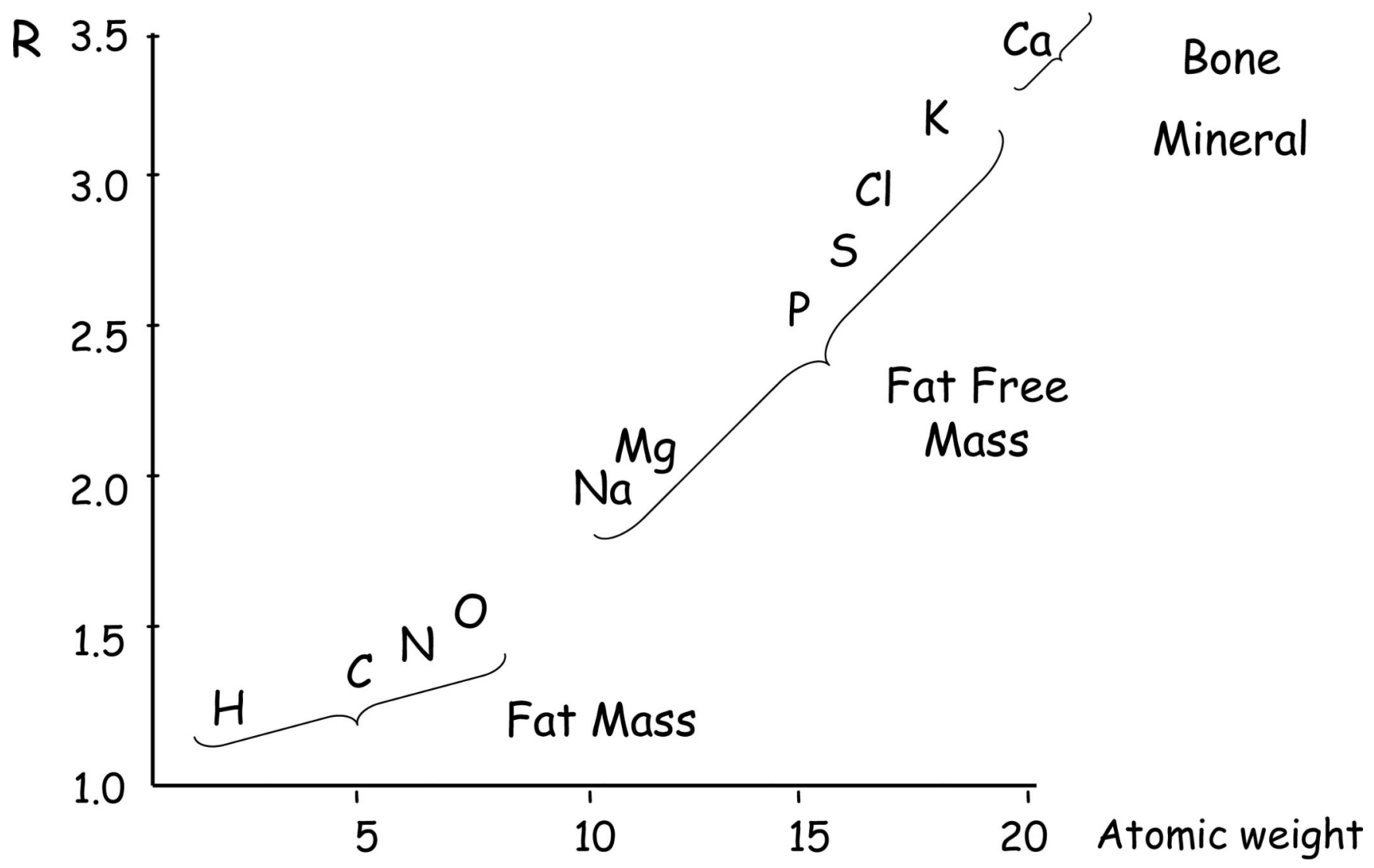

Figure 2. $\mathbf{R}$ of principal elements composing human body

$\mathrm{R}$ is the ratio between the attenuation of the lower energy ray and the higher energy ray. Elements with higher atomic weight (such as calcium) are highly attenuating and have an higher R. Triglycerides (= fat mass), are mainly composed by Hydrogen, $\mathrm{C}$ e O, have a lower value R; intra- and extra-cellular liquids (=lean mass), are composed by $\mathrm{Na}, \mathrm{K}$ and $\mathrm{Cl}$ and have intermediate $\mathrm{R}$ values. Bone mass and hydroxyapatite crystals have higher $\mathrm{R}$ values. 


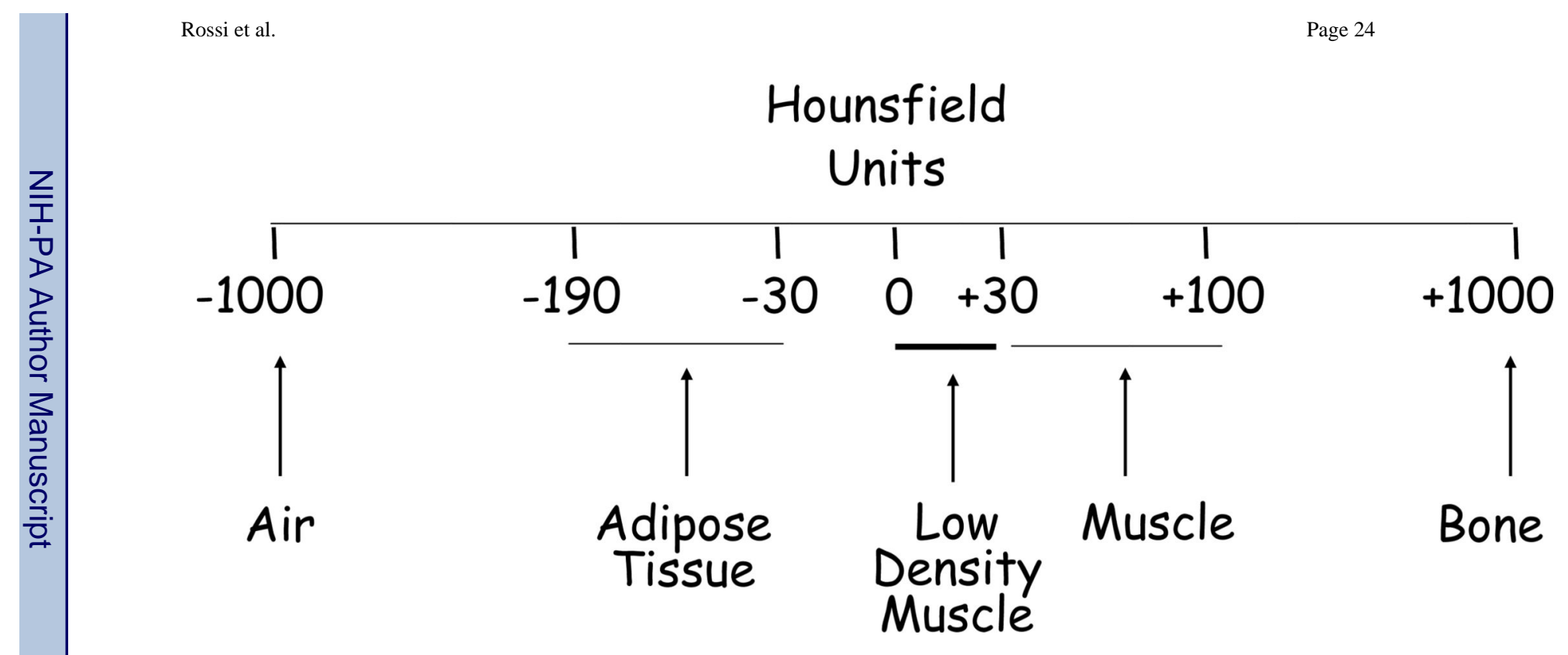

Figure 3. Different tissues attenuation measured in Hounsfiled Units

CT can differentiate tissues based on their attenuation characteristics, which depend on their density. X-ray attenuation is quantified as Hounsfield Units (HU). 


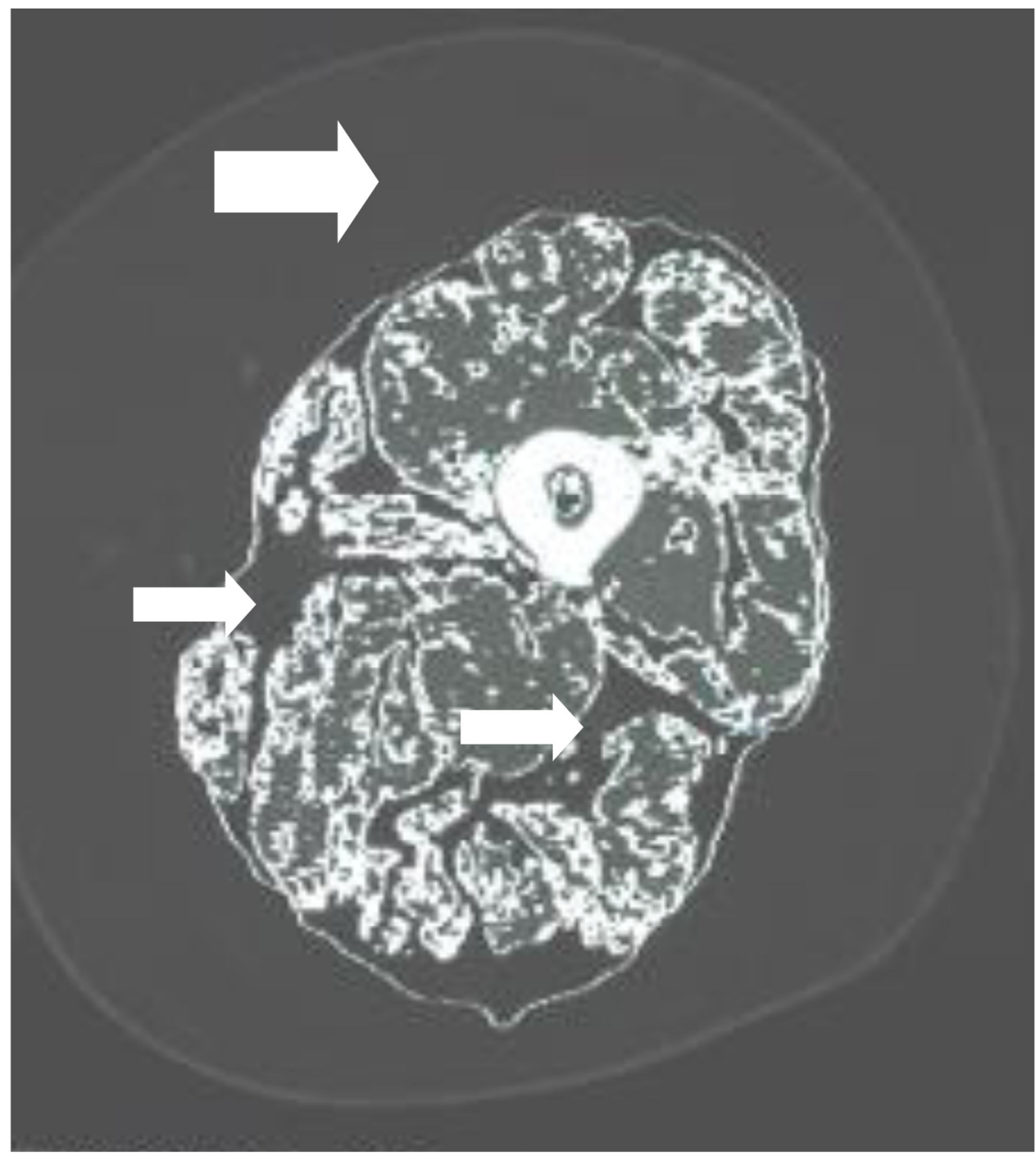

Figure 4. Midthigh CT image of obese elderly subject

CT image obtained in the midthigh in obese elderly subject depicting subcutaneous (large arrow) and intermuscular adipose tissue (small arrows). The lighter appearing pixel within the skeletal muscle tissue have attenuation values between 0 ad 29 HU and represent lowdensity (high-fat) muscle. The darker appearing pixels have attenuation values between 30 and $100 \mathrm{HU}$ and represent high-density (low-fat) muscle. 


\section{Figure 5. Abdominal fat distribution evaluated by MRI}

MRI image of the abdomen at L3 level with subdivision of abdominal adipose tissue into subcutaneous adipose tissue (SCAT) and visceral adipose tissue (VAT). 
Table 1

Weight and dimensions limits of different DXA models

This table lists the different weight limit and dimensions of principal DXA models.

\begin{tabular}{|l|c|c|}
\hline Manufacturer/ Densitometer & Weight Limit kg (lb) & Table Dimensions cm \\
\hline GE Lunar Prodigy Advance & $182(401)$ & $287 \times 132$ \\
\hline GE Lunar Prodigy & $136(300)$ & $197.5 \times 60$ \\
\hline GE Lunar DPX-MD & $136(300)$ & $196.8 \times 57.6$ \\
\hline Hologic QDR series & $136(300)$ & $195.6 \times 65-67$ \\
\hline Hologic Discovery Series & $204(450)$ & $195 \times 65$ \\
\hline Norland XR-46 & $114(250)$ & $193 \times 64$ \\
\hline Norland XR-36 & $114(250)$ & $193 \times 64$ \\
\hline
\end{tabular}


Table 2

Different body composition techniques advantages and disadvantages in older adults

This table lists the different body composition techniques advantages and disadvantages in older adults.

\begin{tabular}{|c|c|c|}
\hline Body composition technique & Advantages & Disadvantages \\
\hline Anthropomertry & 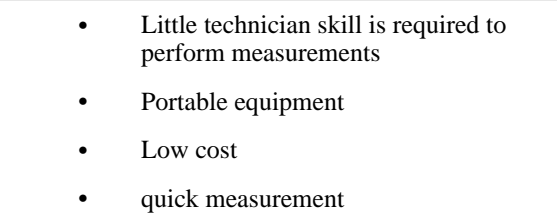 & $\begin{array}{l}\text { - } \quad \text { Low inter-rater reproducibility } \\
\text { - } \quad \text { Arm and leg circumference do not } \\
\text { distinguish between muscle and } \\
\text { subcutaneous fat }\end{array}$ \\
\hline BIA & $\begin{array}{ll}\text { - } & \text { Little technician skill required } \\
\text { - } & \text { Portable equipment } \\
\text { - } & \text { Relatively cheap maintenance } \\
\text { - } & \begin{array}{l}\text { Requires very little from subject, other } \\
\text { than removing one sock and is painless }\end{array}\end{array}$ & $\begin{array}{l}\text { - } \begin{array}{l}\text { Greatly influenced by hydration status of } \\
\text { subject and pooling of fluids in extremities }\end{array} \\
\text { - } \quad \begin{array}{l}\text { Dehydration will cause falsely elevated } \\
\text { body fat percentage }\end{array} \\
\text { - } \quad \text { influenced by ambient temperature } \\
\text { - } \quad \begin{array}{l}\text { Wide range of population specific } \\
\text { equations available }\end{array}\end{array}$ \\
\hline BOD POD & $\begin{array}{ll}\text { - } & \text { Quick measurement } \\
\text { - } & \text { Can host subjects until } 400 \text { kilos } \\
\text { - } & \text { Error Range of } 2 \% \\
\text { - } & \text { Reliability CV }=1.7 \%\end{array}$ & $\begin{array}{l}\text { not portable and subject could become } \\
\text { claustrophobic } \\
\text { - } \quad \text { Expensive }\end{array}$ \\
\hline DXA & $\begin{array}{ll}\text { - } & \text { minimal x-ray exposure }(<1 \mathrm{mrem} \text { for } \\
& 1 \text { scan }) \\
\text { - } & \text { subregion evaluation allowed } \\
\text { - } & \text { quick: total body scan } \\
& \text { Pencil beam DXA }(20-25 \mathrm{~min}) \\
\text { - } & \text { used in large clinical trials } \\
\text { - } & \text { not invasive } \\
\text { - } & \text { Highly precise and reproducible } \\
\text { technique }(\mathrm{CV} \text { for fat mass } 1-1.7 \% \\
\text { and for FFM } 0.7-1.0 \%)\end{array}$ & $\begin{array}{l}\text { - } \quad \text { costs (machine and technicians) } \\
\text { not transportable } \\
\text { - } \quad \text { weight and dimensions limits }\end{array}$ \\
\hline $\mathrm{CT}$ & $\begin{array}{ll}\text { - } & \text { high precision for VAT and SCAT } \\
\text { regions } \\
\text { - } \\
\text { evaluation of muscle quality } \\
\text { parameters (intermuscular fat) } \\
\text { - } \quad \text { Can be used for longitudinal studies }\end{array}$ & $\begin{array}{l}\text { - } \\
\text { - } \quad \text { time-consuming } \\
\text { - } \\
\text { - } \\
\text { high space to requirements } \\
\text { technically difficult to perform }\end{array}$ \\
\hline MRI & $\begin{array}{l}\text { - } \quad \text { Does not use ionizing radiation } \\
\text { - } \quad \text { High quality image and can accurately } \\
\text { quantify both subcutaneous \& visceral } \\
\text { fat } \\
\text { - } \quad \begin{array}{l}\text { Relatively rapid (approx } 30 \text { min for } \\
\text { whole body scan) }\end{array}\end{array}$ & $\begin{array}{l}\text { - } \\
\text { Not available appropriate image analysis } \\
\text { - } \quad \begin{array}{l}\text { Less precise for intermuscular fat } \\
\text { quantification }\end{array} \\
\text { - } \quad \text { Some exclusions (e.g. pacemakers) } \\
\text { - } \quad \text { Expensive }\end{array}$ \\
\hline
\end{tabular}




\begin{tabular}{|c|c|c|}
\hline Body composition technique & Advantages & Disadvantages \\
\hline & & $\begin{array}{l}\text { Artifacts ("shading" at the peripheries of } \\
\text { images due to inhomogeneity in the } \\
\text { magnetic field) }\end{array}$ \\
\hline MRS & $\begin{array}{l}\text { MR spectroscopy accounts for the } \\
\text { multiple spectral components of fatty } \\
\text { acids } \\
\text { - Is the most direct method of fat } \\
\text { quantification inside muscle and } \\
\text { organs }\end{array}$ & $\begin{array}{l}\text { - In vivo abdominopelvic MR spectroscopy } \\
\text { requires a skilled operator to correctly } \\
\text { perform the examination, process the data, } \\
\text { and interpret the results. } \\
\text { - Data analyses is complex, is prone to bias; } \\
\text { and may not permit accurate, reproducible } \\
\text { quantification of all fat signal components. } \\
\text { - Standard MR spectroscopic pulse } \\
\text { sequences have relatively long minimum } \\
\text { echo times (about } 20 \text { and } 30 \text { msec for } \\
\text { STEAM and PRESS, respectively) may } \\
\text { lead to quantification errors. } \\
\text { Shimming the MR spectroscopy voxel } \\
\text { tends to be time consuming and may } \\
\text { lengthen overall examination time } \\
\text { considerably. }\end{array}$ \\
\hline
\end{tabular}

